\title{
EVALUATING LABORATORY PARAMETERS OF COVID-19 CASES WITH UNDERLYING CHRONIC DISEASES
}

\author{
KRONIK HASTALIĞI OLAN COVID-19 VAKALARININ LABORATUVAR \\ PARAMETRELERININ DEĞERLENDIRILMESI
}

\author{
Muhammed Emin DEMIRKOL ${ }^{1}$ (D), Musa KAYA ${ }^{2}$ (D), Süleyman ÖZSARI ${ }^{3}$ (D), Emine ÖZSARI ${ }^{4}$ (D) \\ ${ }^{1}$ Abant Izzet Baysal University, Faculty of Medicine, Department of Internal Medicine, Bolu, Turkey \\ ${ }^{2}$ Zonguldak Ataturk State Hospital, Department of Emergency Medicine, Zonguldak, Turkey \\ ${ }^{3}$ Abant Izzet Baysal University, Faculty of Medicine, Department of Public Health Bolu, Turkey \\ ${ }^{4}$ Abant Izzet Baysal University, Faculty of Medicine, Department of Chest Diseases, Bolu, Turkey
}

ORCID IDs of the authors: M.E.D. 0000-0001-6262-6103; M.K. 0000-0003-4962-2575; S.Ö. 0000-0002-7160-3381;

E.Ö. 0000-0001-5842-7849

Cite this article as: Demirkol ME, Kaya M, Ozsari S, Ozsari E. Evaluating laboratory parameters of COVID-19 cases with underlying chronic diseases. J Ist Faculty Med 2021;84(2):158-64. doi: 10.26650/IUITFD.2020.0101

\begin{abstract}
Objective: COVID-19 infection caused by the SARS-CoV-2 which was initially detected in China during the last days of 2019 has spread to the whole world in a short period of time causing a pandemic with devastating results. In performing this study, we aimed to reveal the differences in laboratory findings of COVID-19 cases accompanied by chronic diseases compared to the cases without any pre-existing medical condition.
\end{abstract}

Methods: This is a retrospective cross-sectional study and consists of 226 patients diagnosed with COVID-19 who applied to health institutions in Bolu, Turkey between 11.03.2020 and 26.05.2020.

Results: The mean age of the patients included in the study was $61.95 \pm 16.82$ ( $\min : 32-\max : 93), 126$ (55.8\%) of the patients were women and 100 (44.2\%) were men. Seventy-five (33.2\%) had at least one chronic disease. The most prevalent comorbid diseases in our patients were found to be hypertension (15.9\%), chronic obstructive pulmonary disease $(14.6 \%)$ and diabetes mellitus (9.7\%). Findings such as leukocytosis, basophilia and neutrophilia, elevated CRP, elevated D-DIMER and elevated LDH, which are relatively common in COVID-19 cases, were more extensive in cases accompanied by underlying diseases.

Conclusion: Impaired laboratory findings of COVID-19 patients with concomitant chronic diseases are more severe than the group without additional disease. We recommend that there can be more studies in which all parameters that may affect the results are evaluated.

Keywords: COVID-19, chronic diseases, laboratory findings

\section{ÖZET}

Amaç: 2019 yılının son günlerinde ilk olarak Çin'de tespit edilen SARS-CoV-2 (Yeni Tip Coronavirüs) virüsünün sebep olduğu COVID-19 enfeksiyonu kısa bir zaman diliminde, bütün dünyaya yayılarak yıkıcı sonuçlara sebep veren pandemiye yol açmıştır. Bu çalışma ile kronik hastalığı olan COVID-19 vakalarının eşlik eden herhangi bir hastalığı olmayan vakalara kıyasla laboratuvar bulgularındaki farklılıkları ortaya koymayı amaçladık.

Gereç ve Yöntem: Bu çalışma kesitsel tipte retrospektif özellikte olup 11.03.2020 ve 26.05.2020 tarihleri arasında Bolu'daki sağlık kurumlarına başvurup COVID-19 tanısı almış 226 hastadan oluşmaktadır.

Bulgular: Çalışmaya dahil edilen 226 hastanın yaş ortalamasının

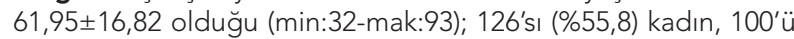
$(\% 44,2)$ erkek hasta olup, 75 (\%33,2)'inin kronik bir hastalığının olduğu saptanmıştır. Hastalarımızda en sık görülen komorbid hastalıkların hipertansiyon (\%15,9), kronik obstrüktif akciğer hastalığı $(\% 14,6)$ ve diabetes mellitus $(\% 9,7)$ olduğu görüldü. COVID-19 vakalarında sık olarak rastlanan lökositoz, nötrofili ve bazofilinin; ayrıca CRP, LDH ve D-DiMER yüksekliğinin, komorbid hastalığı olan vakalarda olmayanlara göre daha yaygın olduğu saptanmıştır.

Sonuç: Eşlik eden kronik hastalıkları olan COVID-19 hastalarına ait bozulmuş laboratuvar bulguları ek hastalığı olmayan gruba göre daha ciddi seyretmektedir. Sonuçları etkileyebilecek tüm parametrelerin değerlendirildiği yeni çalışmalara ihtiyaç vardır.

Anahtar Kelimeler: COVID-19, kronik hastalıklar, laboratuvar bulguları

Corresponding author/iletişim kurulacak yazar: medemirkol@hotmail.com

Submitted/Başvuru: 14.05.2020 • Revision Requested/Revizyon Talebi: 20.05.2020 •

Last Revision Received/Son Revizyon: 12.08.2020 • Accepted/Kabul: 09.09.2020 • Published Online/Online Yayın: 15.03 .2021 


\section{INTRODUCTION}

Following its emergence in China in the last days of 2019, COVID-19 infection caused by the SARS-CoV-2 (Novel Coronavirus) spread all over the world in a short period of time, causing a pandemic with devastating results (1). As shown in prior studies, the main symptoms are known to be fever, cough and dyspnea. However, apart from the most common ones, various symptoms such as headache, malaise, diarrhea, nausea, vomiting, and runny nose are likely to be encountered. Although the disease manifests itself with mild symptoms in most of the cases, it has been revealed that vital organs such as heart, liver and kidney may be affected as much as the respiratory system with a rapid progression causing ARDS and/or sepsis (2). The incidence of clinical findings and the prognosis of the disease in the presence of co-existing diseases have been previously investigated and it has been concluded that severe disease is more common in patients with underlying chronic diseases (3).

It has been found that the duration of hospitalization stay is longer and the incidence of serious complications and mortality are higher in patients with comorbid diseases $(4,5)$. Some previous studies have investigated the severity of the disease, the requirement of mechanical ventilation and intensive care and the mortality rates in COVID-19 cases with underlying chronic diseases. In this retrospective study, we aimed to reveal the differences in biochemical laboratory parameters of COVID-19 patients with underlying chronic diseases compared to those without chronic diseases. Through this study, we will have the opportunity to evaluate the incidence of laboratory abnormalities in COVID-19 cases in cases with underlying chronic diseases.

\section{MATERIALS AND METHODS}

This is a cross-sectional and retrospective study. The study was conducted with COVID-19 patients whose diagnosis was confirmed by Real-time PCR (RT-PCR) test after being admitted to health institutions affiliated with the City Health Administrative of Bolu, Turkey between 11.03.2020 and 26.05.2020. Ethical approval of the study was obtained from Bolu Abant Izzet Baysal University Clinical Research Ethics Committee (Date: 22.07.2020, Number: 335). The hospital information management system was used for data collection. Laboratory parameters such as white blood cell count $(\mathrm{WBC})$, red blood cell count (RBC), lymphocyte count (LYM), basophil count (BASO), neutrophil count (NEU), hemoglobin concentration (HGB), platelet count (PLT), plateletcrit (PCT), C-reactive protein (CRP), lactate dehydrogenase (LDH) and D-DIMER were analyzed in all the COVID-19 patients.
The analysis of the data was carried out in the SPSS ver. 21 (IBM Corp, Armonk, NY, USA). Descriptive statistical methods (frequency, arithmetic mean, standard deviation, cross tables) were used. The suitability of the distribution of the data to the normal distribution was checked by the skewness and kurtosis coefficients and the \pm 1 interval was taken as reference. For normally distributed data, Independent Samples T Test and one-way ANOVA (One Way ANOVA) were used, and data, which were not suitable for normal distribution, were analyzed with Mann-Whitney $U$ test and Kruskal Wallis test. For data, which fit a normal distribution, Scheffe test was used in case of homogeneity of variances from post-hoc tests. Chi-square test was used in the analysis of categorical data.

\section{RESULTS}

The mean age of 226 patients included in the study was found to be $61.95 \pm 16.82$ years (min:32-max:93); 110 (48.7\%) of the patients were found to be aged 32-64 and $116(51.3 \%)$ were 65 and over. One hundred twenty-six (55.8\%) of the patients were women and 100 (44.2\%) were men. Of 226 patients, 75 (33.2\%) had chronic diseases (Table 1).

Table 1: Demographic features of the patients

\begin{tabular}{lccc}
\hline $\begin{array}{l}\text { Demographic } \\
\text { features }\end{array}$ & $\bar{x} \pm$ SS & \multicolumn{2}{c}{ min-max } \\
\hline Mean age & $61.95 \pm 16.82$ & \multicolumn{2}{c}{$32-93$} \\
& & $\mathbf{n}$ & $\%$ \\
\hline Age groups & $32-64$ & 110 & 48.7 \\
& 65 and over & 116 & 51.3 \\
Gender & Female & 126 & 55.8 \\
& Male & 100 & 44.2 \\
Presence of & Yes & 75 & 33.2 \\
chronic diseases & No & 151 & 66.8 \\
\hline
\end{tabular}

The proportion of hypertension (HT), chronic obstructive pulmonary disease (COPD), diabetes, malignancy, cardiovascular diseases, chronic renal failure and cerebrovascular diseases were $36(15.9 \%), 33(14.6 \%), 22$ (9.7\%), $8(3.5 \%), 6(2.7 \%), 5(2.2 \%)$ and $2(0.9 \%)$, respectively (Table 2).

The deviations in the reference ranges of the laboratory parameters were as follows; the rate of WBC, RBC, LYM, HGB and PLT parameters which were below the reference range was found to be higher in patients with underlying chronic disease compared to those without chronic diseases and the rate of NEU, D-DIMER, LDH and CRP parameters which were above the reference range was higher in patients with chronic diseases 
Table 2: Distribution of underlying chronic diseases

\begin{tabular}{lccc}
\hline & $\begin{array}{c}\text { Presence of } \\
\text { chronic diseases }\end{array}$ & $\mathbf{n}$ & $\%$ \\
\hline HT & Yes & 36 & 15.9 \\
Diabetes & No & 190 & 84.1 \\
& Yes & 22 & 9.7 \\
Malignancy & No & 204 & 90.3 \\
& Yes & 8 & 3.5 \\
COPD & No & 218 & 96.5 \\
& Yes & 33 & 14.6 \\
Heart diseases & No & 193 & 85.4 \\
Cerebrovascu- & Yes & 6 & 2.7 \\
lar diseases & No & 220 & 97.3 \\
Chronic renal & Yes & 2 & 0.9 \\
failure & No & 224 & 99.1 \\
\hline
\end{tabular}

HT: Hypertension, COPD: Chronic Obstructive Pulmonary Disease

(Table 3). As for the comparison of the results of the laboratory parameters according to presence or absence of underlying chronic diseases, BASO, NEU, D-DIMER, $L D H, C P R$ and WBC differed significantly $(p<0.05)$. The mean BASO, NEU, D-DIMER, LDH, CRP and WBC values of the patients with underlying chronic diseases were found to be statistically significantly higher than those without any chronic disease (Table 4).
WBC, RBC, HGB, NEU, MONO and CRP values were significantly higher for female patients, while PLT and PCT values were significantly higher for male patients. LYM, BASO, D-DIMER and LDH values did not differ significantly according to sex. RBC, LYM and HGB were significantly higher for female patients, while NEU, D-DIMER and CRP values were significantly higher for male patients. WBC, BASO, PLT, MONO, LDH and PCT values did not differ significantly according to age groups (Table 5 ).

\section{DISCUSSION}

In this study, performed to analyze the laboratory abnormalities of COVID-19 cases with underlying chronic diseases, we revealed that HT was the most common comorbidity among our patients compatible with prior studies $(6,7)$. It has been reported that the severity and mortality of COVID-19 infection in patients with a diagnosis of HT may show an increase even in patients aged under 50 (8). COPD and diabetes were the other common underlying diseases among our COVID-19 patients. Also patients with diabetes (9) and those with a history of COPD and/or smoking have been found to be associated with increased risk of severe disease and mortality (10). Other co-existing chronic diseases were heart diseases, cerebrovascular diseases, malignancies and chronic renal failure in our patients. Venkatesulu et al., concluded that COVID-19 infection is more severe with increasing need for intensive care and significantly increased mortality rates in cancer patients compared to other cases (11). Similarly, it is known that the course of COVID-19 infection may be unfavorable in cases accompanied by cardiovascular and cerebrovascular diseases (12).

Table 3: Results of laboratory parameters according to reference ranges

\begin{tabular}{|c|c|c|c|c|c|c|}
\hline \multirow[b]{2}{*}{ Parameters } & \multicolumn{3}{|c|}{ Presence of chronic diseases } & \multicolumn{3}{|c|}{ Absence of chronic diseases } \\
\hline & $\begin{array}{l}\text { Low } \\
\text { n (\%) }\end{array}$ & $\begin{array}{c}\text { Normal } \\
\text { n (\%) }\end{array}$ & $\begin{array}{l}\text { High } \\
\text { n (\%) }\end{array}$ & $\begin{array}{l}\text { Low } \\
\text { n (\%) }\end{array}$ & $\begin{array}{c}\text { Normal } \\
\text { n (\%) }\end{array}$ & $\begin{array}{l}\text { High } \\
\text { n (\%) }\end{array}$ \\
\hline WBC (4.5-11.0) & $27(36 \%)$ & $45(60 \%)$ & $3(4 \%)$ & $24(15.9 \%)$ & $102(67.5 \%)$ & $25(16.6 \%)$ \\
\hline RBC (3.90-5.50) & $15(20 \%)$ & $57(76 \%)$ & $3(4 \%)$ & $17(11.3 \%)$ & $129(85.4 \%)$ & $5(3.3 \%)$ \\
\hline LYM (1.1-5.1) & 35 (46.6\%) & 40 (53.4\%) & $0(0 \%)$ & $53(35.1 \%)$ & 98 (64.9\%) & $0(0 \%)$ \\
\hline HGB (11.5-17.5) & $13(17.3 \%)$ & $61(81.3 \%)$ & $1(1.3 \%)$ & $21(13.9 \%)$ & $130(86.1 \%)$ & $0(0 \%)$ \\
\hline BASO (0-0.1) & - & 65 (86.7\%) & $10(13.3 \%)$ & - & $131(86.8 \%)$ & 20 (13.2\%) \\
\hline PLT (140-400) & $17(22.6 \%)$ & $58(77.4 \%)$ & $0(0 \%)$ & $17(11.3 \%)$ & $134(88.7 \%)$ & $0(0 \%)$ \\
\hline РCТ (0-9.99) & - & 75 (100\%) & $0(0 \%)$ & - & $150(99.3 \%)$ & $1(0.7 \%)$ \\
\hline NEU (1.8-7.3) & $3(4 \%)$ & $41(54.7 \%)$ & $31(41.3 \%)$ & $4(2.6 \%)$ & $109(72.2 \%)$ & $38(25.2 \%)$ \\
\hline D-DIMER (0-0.55) & - & $20(26.7 \%)$ & 47 (62.7\%) & - & 65 (43.0\%) & 70 (46.4\%) \\
\hline LDH (125-220) & $1(1.3 \%)$ & $13(17.3 \%)$ & 51 (68\%) & $1(0.7 \%)$ & 52 (34.4\%) & 89 (58.9\%) \\
\hline CRP (0-5) & - & 9 (12\%) & 66 (88\%) & - & 51 (33.8\%) & 100 (66.2\%) \\
\hline
\end{tabular}

WBC: White Blood Cell, RBC: Red Blood Cell, LYM: Lymphocyte, BASO: Basophil, NEU: Neutrophil, HGB: Hemoglobin, PLT: Platelet, PCT: platetetcrit, CRP: C - reactive protein, LDH: Lactate Dehydrogenase 
Table 4: Comparison of laboratory parameters according to presence or absence of underlying diseases

\begin{tabular}{|c|c|c|c|}
\hline & Patients with chronic diseases & Patients without chronic diseases & \multirow{2}{*}{ p-value } \\
\hline & \multicolumn{2}{|c|}{ Median (Min-Max) } & \\
\hline $\mathrm{RBC}$ & $4.45(2.99-5.78)$ & $4.64(1.08-6.53)$ & 0.275 \\
\hline LYM & $1.30(0.32-4.36)$ & $1.39(0.28-4.75)$ & 0.799 \\
\hline HGB & $13.20(8.10-18.20)$ & $13.70(3.69-17.20)$ & 0.088 \\
\hline BASO & $0.068(0.00-0.50)$ & $0.046(0.00-0.80)$ & $0.035^{*}$ \\
\hline PLT & $239(67-712)$ & $212(20.50-511.0)$ & 0.085 \\
\hline NEU & $6.68(0.39-21.70)$ & $4.60(0.00-17.40)$ & 0.001 * \\
\hline MONO & $0.60(0.10-1.78)$ & $0.50(0.05-1.80)$ & 0.056 \\
\hline D-DIMER & $1.01(0.19-19.93)$ & $0.58(0.03-16.89)$ & $0.011 *$ \\
\hline $\mathrm{LDH}$ & $290(113-1491)$ & $244(54-644)$ & 0.010 * \\
\hline \multirow[t]{2}{*}{ CRP } & $38(0-355)$ & $30(0-242)$ & $0.042^{*}$ \\
\hline & \multicolumn{3}{|c|}{ Mean \pm Std. Deviation ${ }^{\star \star \star}$} \\
\hline WBC & $9.48 \pm 4.34$ & $7.78 \pm 3.56$ & $0.002^{*}$ \\
\hline PCT & $0.19 \pm 0.071$ & $0.180 \pm 0.055$ & 0.275 \\
\hline
\end{tabular}

${ }^{*} \mathrm{~A}$ value of $\mathrm{p}<0.05$ was taken as statistically significant, ${ }^{* \star}$ Mann-Whitney $U$ test, ${ }^{\star \star \star}$ Independent Sample $t$ test; WBC: White Blood Cell, RBC: Red Blood Cell, LYM: Lymphocyte, BASO: Basophil, NEU: Neutrophil, HGB: Hemoglobin, PLT: Platelet, PCT: plateletcrit, CRP: $\mathrm{C}$ - reactive protein, LDH: Lactate Dehydrogenase

In a study conducted with 212 patients, $42 \%$ of whom had at least one chronic disease, it was reported that COVID-19 infection led to a longer hospital stay and poor prognosis in the presence of comorbid diseases. Moreover, it has been suggested that underlying chronic diseases are highly likely to increase mortality rates by causing severe damage to vital organs such as heart, liver and kidney (13). Some laboratory tests are required to detect the dysfunction of these essential organs. The results of the tests can not only support the diagnosis of COVID-19, but also provide information about the prognosis. It has been shown that certain laboratory tests such as complete blood count, LDH, CRP, AST and ALT may be supportive in the diagnosis of COVID-19 even if a confirmation is provided via a RT-PCR test. Accordingly, increased levels of AST, ALT, LDH and CRP and lymphopenia are the most common laboratory abnormalities in COVID-19 infection (14). Furthermore, increased levels of D-DIMER may be used as a helpful tool in both diagnosis and prognosis of COVID-19 infection (15).

About gender and age for underlying diseases, there are few researches, especially with angiotensin converting enzyme (ACE) 2 receptor polymorphism (16-20). Ambrossino et al., underlined that being male and having chronic diseases like DM and HT are more relatively about mortality (16). Circulating ACE2 activity is increased in cardiovascular complications, so COVID-19 can be more serious in younger than older patients (17). Most re- searchers also state that morbidity and mortality could be connected with smoking, obesity, and proinflamatory cytokines such as TNF- $\alpha$, IL-6, or C-reactive protein (18-20). In our study, WBC, RBC, HGB, NEU and monocyte values were lower in males than females, also CRP and PCT were higher in males, which was statistically different. About ages, RBC, LYM and HGB were lower in the 32-64 group whereas CRP, D-DIMER and NEU were statistically higher in the 65 and above group.

In this study, we aimed to reveal to what extent the laboratory tests, which have been previously shown to be helpful in the of diagnosis and prognosis of COVID-19, differ in cases with underlying chronic disease compared to those without any comorbidity. We found that the laboratory abnormalities such as lymphopenia, elevated CRP, LDH and D-DIMER, which are mostly anticipated findings in COVID-19 infection, have a higher incidence in cases that have underlying chronic diseases.

In addition, we also determined that the mean values of D-DIMER, CRP and LDH were statistically significantly higher in the group with chronic disease. Since COVID-19 cases with chronic comorbid diseases have a poor prognosis and higher mortality rates, it is inevitable to see more laboratory abnormalities compared to the other COVID-19 cases. Even though we could not make a clear evaluation regarding mortality because of the very low mortality rate among the cases in our study, previ- 
Table 5: Comparison of laboratory parameters according to gender and age

\begin{tabular}{|c|c|c|c|}
\hline \multicolumn{4}{|c|}{ Comparison of laboratory parameters according to age } \\
\hline & Female & Male & n-value \\
\hline & \multicolumn{2}{|c|}{ Median $\left(\right.$ Min-Max) ${ }^{\star \star}$} & p-value \\
\hline WBC & $8.47(1.80-25.20)$ & $6.40(1.25-18.50)$ & $0.001 *$ \\
\hline $\mathrm{RBC}$ & $4.74(1.71-6.00)$ & $4.41(1.08-6.53)$ & $0.000^{*}$ \\
\hline LYM & $1.30(0.30-4.75)$ & $1.36(0.28-4.46)$ & 0.839 \\
\hline HGB & $14.10(5.50-18.20)$ & $12.65(3.69-18.80)$ & $0.000^{*}$ \\
\hline BASO & $0.60(0.00-0.50)$ & $0.06(0.00-0.80)$ & 0.388 \\
\hline PLT & $206.5(20.50-712.00)$ & $235.50(67.00-477.00)$ & $0.004^{\star}$ \\
\hline NEU & $5.91(0.00-21.70)$ & $4.12(0.39-17.40)$ & $0.001 *$ \\
\hline MONO & $0.66(0.10-1.80)$ & $0.42(0.05-1.61)$ & $0.000^{*}$ \\
\hline D-DIMER & $0.77(0.03-19.93)$ & $0.61(0.11-18.79)$ & 0.527 \\
\hline LDH & $243.50(54.90-1491.00)$ & $259.00(113.00-686.00)$ & 0.700 \\
\hline \multirow[t]{2}{*}{ CRP } & $52.50(0.00-272.00)$ & $11.90(0.00-355.00)$ & $0.000^{*}$ \\
\hline & \multicolumn{2}{|c|}{ Mean \pm Std. Deviation ${ }^{\star * *}$} & \\
\hline \multirow[t]{3}{*}{ PCT } & $0.17 \pm 0.06$ & $0.19 \pm 0.05$ & $0.001 *$ \\
\hline & $32-64$ & 65 and over & \multirow{2}{*}{ p-value } \\
\hline & \multicolumn{2}{|c|}{ Median $($ Min-Max)** } & \\
\hline WBC & $7.00(3.10-25.20)$ & $8.07(1.25-18.50)$ & 0.122 \\
\hline RBC & $4.83(2.99-6.53)$ & $4.34(1.08-5.78)$ & $0.000^{*}$ \\
\hline LYM & $1.79(0.28-4.75)$ & $1.02(0.30-4.36)$ & $0.000^{*}$ \\
\hline HGB & $14.00(7.30-18.20)$ & $12.80(3.69-17.20)$ & $0.000 *$ \\
\hline BASO & $0.05(0.00-0.18)$ & $0.57(0.00-0.80)$ & 0.283 \\
\hline PLT & $215.00(67.00-477.00)$ & 215.00 (20.50-712.00) & 0.838 \\
\hline NEU & $4.50(1.30-21.70)$ & $6.45(0.00-17.40)$ & $0.001 *$ \\
\hline MONO & $0.56(0.06-1.80)$ & $0.57(0.05-1.78)$ & 0.425 \\
\hline D-DIMER & $0.42(0.03-13.40)$ & $1.27(0.16-19.93)$ & $0.000^{*}$ \\
\hline LDH & $241.00(143.00-1491.00)$ & $266.00(54.90-686.00)$ & 0.128 \\
\hline \multirow[t]{2}{*}{ CRP } & $9.36(0.00-265.00)$ & $50.20(0.00-355.00)$ & $0.000^{*}$ \\
\hline & \multicolumn{2}{|c|}{ 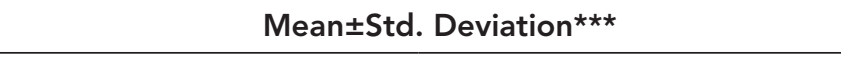 } & \\
\hline PCT & $0.185 \pm 0.059$ & $0.182 \pm 0.063$ & 0.758 \\
\hline
\end{tabular}

ous studies have shown that the presence of co-existing chronic diseases leads to many serious complications including increased mortality rates $(5,8-12)$. Considering patients with poor prognosis will have more laboratory abnormalities than others, our study, which revealed more abnormal laboratory findings in patients with underlying chronic diseases, showed an expected result in accordance with many prior studies, which suggested that the presence of comorbidities is associated with a poor prognosis. 


\section{CONCLUSIONS}

Laboratory abnormalities, which are indicative for prediction of poor prognosis, are inclined to be more common in patients with underlying chronic diseases. We suggest that laboratory abnormalities should be considered to be used in prediction of complications of COVID-19 patients, especially in those with underlying chronic diseases.

Ethics Committee Approval: This study was approved by the Bolu Abant Izzet Baysal University Clinical Research Ethics Committee (Date:22.07.2020, No:335).

Informed Consent: Written consent was obtained from the participants.

Peer Review: Externally peer-reviewed.

Author Contributions: Conception/Design of Study- M.E.D., M.K.; Data Acquisition- M.E.D., M.K., S.Ö.; Data Analysis/Interpretation- M.E.D., M.K., E.Ö.; Drafting Manuscript- M.E.D., M.K.; Critical Revision of Manuscript- M.E.D., M.K., E.Ö., S.Ö.; Final Approval and Accountability- M.E.D., M.K., E.Ö., S.Ö.

Conflict of Interest: Authors declared no conflict of interest.

Financial Disclosure: Authors declared no financial support.

Etik Komite Onayı: Bu çalışma için etik komite onayı Bolu Abant İzzet Baysal Üniversitesi, Klinik Araştırmalar Etik Kurulu'ndan alınmıştır (Tarih:22.07.2020, Sayı:335).

Bilgilendirilmiş Onam: Katılımcılardan bilgilendirilmiş onam alınmıştır.

Hakem Değerlendirmesi: Dış bağımsız.

Yazar Katkıları: Çalışma Konsepti/Tasarım- M.E.D., M.K.; Veri Toplama- M.E.D., M.K., S.Ö.; Veri Analizi/Yorumlama- M.E.D., M.K., E.Ö.; Yazı Taslağı- M.E.D., M.K.; İçeriğin Eleştirel İncelemesi- M.E.D., M.K., E.Ö., S.Ö.; Son Onay ve Sorumluluk- M.E.D., M.K., E.Ö., S.Ö.

Çıkar Çatışması: Yazarlar çıkar çatışması beyan etmemişlerdir.

Finansal Destek: Yazarlar finansal destek beyan etmemişlerdir.

\section{REFERENCES}

1. Wu Z, Mc Googan JM. Characteristics of and Important Lessons From the Coronavirus Disease 2019 (COVID-19) Outbreak in China. Summary of a Report of 72314 Cases From the Chinese Center for Disease Control and Prevention. JAMA 2020;323(13):1239-42. [CrossRef]

2. Chen N, Zhou M, Dong $X$, Qu J, Gong F, Han Y, et al. Epidemiological and clinical characteristics of 99 cases of 2019 novel coronavirus pneumonia in Wuhan, China: a descriptive study. Lancet. 2020;395(10223):507-13. [CrossRef]
3. Guan WJ, Ni ZY, Hu Y. Clinical characteristics of coronavirus disease 2019 in China. N Engl J Med 2020. [CrossRef]

4. Yang R, Gui X, Zhang Y, Xiong Y. The role of essential organbased comorbidities in the prognosis of COVID-19 infection patients. Expert Rev Respir Med 2020;1-4. [CrossRef]

5. Nandy K, Salunke A, Pathak SK, et al. Coronavirus disease (COVID-19): A systematic review and meta-analysis to evaluate the impact of various comorbidities on serious events. Diabetes Metab Syndr 2020;14(5):1017-25. [CrossRef]

6. Zhou F, Yu T, Du R, Fan G, Liu Y, Liu Z, et all. Clinical features of patients infected with 2019 novel coronavirus in Wuhan, China. Lancet 2020; 395:497-506. [CrossRef]

7. Wu C, Chen X, Cai Y, Xia J, Zhou X, Xu S, et al. Risk factors associated with acute respiratory distress syndrome and death in patients with coronavirus disease 2019 pneumonia in Wuhan, China. JAMA Intern Med 2020;180(7):934-43. [CrossRef]

8. Zhang J, Wu J, Sun X, et al. Association of hypertension with these verity and fatality of SARS-CoV-2 infection: A meta-analysis. Epidemiol Infect 2020;148:e106. Published online 2020 May 28. [CrossRef]

9. Wu ZH, Tang Y, Cheng $\mathrm{Q}$. Diabetes increases the mortality of patients with COVID-19: a meta-analysis .Acta Diabetol. 2020: 1-6. [CrossRef]

10. Alqahtani JS, Oyelade T, Aldhahir AM, et al. Prevalence, Severity and Mortality associated with COPD and Smoking in patients with COVID-19: A Rapid Systematic Review and Meta-Analysis. PLoSOne 2020;15(5):e0233147. [CrossRef]

11. Venkatesulu BP, Chandrasekar VT, Girdhar P, et al. A systematic review and meta-analysis of cancer patients affected by a novel coronavirus. medRxiv. Preprint 2020 May 29. [CrossRef]

12. Pranata R, Huang I, Lim MA, Wahjoepramono PEJ, July J. Impact of Cerebrovascular and Cardiovascular Diseases on Mortality and Severity of COVID-19 - Systematic Review, Meta-analysis, and Meta-regression. J Stroke Cerebrovasc Dis 2020;29(8):104949. Published online 2020 May 14. [CrossRef]

13. Yang R, Gui X, Zhang Y, Xiong Y. The role of essential organbased comorbidities in the prognosis of COVID-19 infection patients. Expert Rev Respir Med 2020:1-4.Published online 2020 Apr 28. [CrossRef]

14. Ferrari D, Motta A, Strollo M, Banfi G, Locatelli M. Routine blood tests as a potential diagnostic tool for COVID-19. Clin Chem Lab Med 2020;58(7):1095-9. [CrossRef]

15. Zhang L, Yan X, Fan Q, et al. D-dimer levels on admission to predict in-hospital mortality in patients with Covid-19. J Thromb Haemost 2020;18(6):1324-9. [CrossRef]

16. Ambrosino I, Barbagelata E, Ruggieri A, Massiah G ,Giannico O, Politi C, et al. Gender differences in patients with COVID-19: a narrative review. Monaldi Archives for Chest Disease 2020;90:138. [CrossRef]

17. Gemmati D, Bramanti B, Serino ML, Secchiero P, Zauli G. COVID-19 and Individual Genetic Susceptibility/Receptivity: Role of ACE1/ACE2 Genes, Immunity, Inflammation and Coagulation. Might the Double X-chromosome in Females Be Protective against SARS-CoV-2 Compared to the Single X-Chromosome in Males?. Int J Mol Sci 2020;21(10);3474. [CrossRef]

18. Gargaglioni LH, Marques DA. Let's talk about sex in the context of COVID-19. J Appl Physiol 2020;128(6):1533-8. [CrossRef] 
Laboratory findings in COVID-19 and chronic disease

İstanbul Tıp Fakültesi Dergisi • J Ist Faculty Med 2021;84(2):158-64

19. Gebhard C, Regitz-Zagrosek V, Neuhauser HK, Morgan R, Klein SL. Impact of sex and gender on COVID-19 outcomes in Europe. Biol Sex Differ 2020;11(1):29. [CrossRef]
20. Neha C, Tsering P, Kavita S, Rahul K, Brian B, Qadar P. Sexderived attributes contributing to SARS-CoV-2 mortality. Am J Physiol Endocrinol Metab 2020;319(3):E562-7. [CrossRef] 